\title{
Antimetastatic and Tumor Growth Inhibition Activity of Polysaccharide from Helianthus Tuberosus $L$.
}

\author{
Generalov A. Evgenii \\ PhD Student, \\ Engelhardt Institute of Molecular Biology Russian Academy of Sciences, \\ 119991, Moscow, Russia \\ generals1179@gmail.com
}

\begin{abstract}
In order to study antitumor and antimetastatic activity of polysaccharide from Helianthus tuberosus L. in vitro and in vivo models were chosen. Hep-2 (laryngeal) and L-929 (mice fibroblasts) were taken for in vitro studies. Also to investigate antimetastatic activity of natural glucan the high-affinity strain of Walker carcinosarcoma was used, which forms tumor nodules after intravenous injection. Dose-dependent activity of polysaccharide was also studied. Stimulation of Nk-cells activity by HTLP was shown. Conclusion about immunological way of antimetastatic and antitumor activity was made. To verify antimetastatic activity and influence on primary tumor by polysaccharide was Lewis lung-carcinoma model was also taken.
\end{abstract}

Keywords: polysaccharide, antimetastatic activity, antitumor activity, Helianthus tuberosus L., Nk-cell activity.

\section{INTRODUCTION}

This study was undertaken to prove hypothesis that polysaccharide from Helianthus tuberosus L. has antimetastatic and antitumor activities due to immunomodulating activity and proapoptotic activities in tumors, by triggering cytokines cascades, activating immune system especially Nk-cells and colonystimulation.

Such an approach to the antitumor therapy and preventing metastasis, which is based on the activation of innate immune system - stimulation of Nk-cells activity,what leads to thegrowth of the cytotoxicity index, cytokines cascades, and apoptosis in tumor cells can be considered as a development of immune therapy of cancer $[1,2]$.

At the same time various scientific groups proved broad range of polysaccharide activity, especially immunological [3-5]. Moreover it was shown that polysaccharides can demonstrate antitumor [6], antimetastatic, what was shown for glucan structurally similar to HTLP [7], cytotoxic and apoptosis stimulating in tumor cells K562 anf Hep-2 [8, 9], activity in wide variety of biological both in vivo and in vitro models. Some of authors propose that polysaccharides have antitumor, antimetastatic activity due to immunological activity [10].The polysaccharide from Helianthus tuberosus L. was studied as immunomodulatory in previous work in different models and influencing different cytokines IL-1, IL-6, TNF [3].

It is proposed that polysaccharide from Helianthus tuberosus L. possess immunomodulatory activity and activation of immune system that strikes tumor and metastases.

In this work, the results of studying the antitumor activity of polysaccharide from Helianthus tuberosus L. in models of transplanted animal tumors, such as Lewis lung-carcinoma, Walker carcinosarcoma are presented; as well, an evaluation of the and in vivo effect of HTLP on cancer cell lines L-929 and Hep-2 and on the immune system through stimulating Nk-cells activity is given.

\section{Materials AND Methods}

\subsection{Preparation}

Polysaccharide from Helianthus tuberosus L. (HTLP) was obtained from Ltd. PtePolylab laboratory from Singapore.Substance is pale grey-grey odorless water-soluble powder, high hygroscopic. In experiments were used $0.1,0.2 \mathrm{mg} / \mathrm{ml}$ water and $0.9 \% \mathrm{NaCl}$ solutions of carbohydrate. 


\subsection{Laboratory Animals}

Experiments were performed in 100-130 g «Avgust»breed ratsand 20-25 g C57BL/6 inbred mice, from Stolbovaya nursery of the Russian Academy of Medical Sciences. In tests were used both male and female rats and mice.

\subsection{Experimental models}

\subsubsection{Stimulation of Nk-cells activity by HTLP}

For in vitro study of influence of HTLP on the activity of Nk-cells human myeloleucosis (K-562) as a target cells, stained with $3 \mathrm{H}$-uridin in $3 \mu \mathrm{Ci}$ per $1 \mathrm{ml}$ of culture media were taken. K-562 cell line then was used in amount 105 per experimental point. As an effector cells peripheral blood lymphocytes (PBL) were taken. For that human blood from 5 donors, after test for immune status, was incubated with $100 \mathrm{U} / \mathrm{ml}$ heparin and diluted 1:2 with balance saline and layered on the phycoll-sodium metriozat, with density 1.077. After that solution was centrifuged for 15 minutes at $1000 \mathrm{~g}$. PBL layer, which formed on the boundary between the plasma-phycoll, was collected and washed twice in a balanced saline solution. To check cytotoxic reaction PBL from donors with normal immune status were taken. Effector cells were cultivated in vitro with $100 \mu \mathrm{g} /$ well HTLP in U-bottom 96-well plate for 24 hours. In each well was placed $100 \mu \mathrm{l}$ of effector cell suspension in total 107 cells and target cells at a ratio 100:1 and $10 \mu \mathrm{l}$ of RNase $(5 \mu \mathrm{g} / \mathrm{ml})$. Each dilution was repeated 5 times. Target cells without effector cells and target cells incubated with HTLP (same amount) were used as a control. Plate was incubated in $\mathrm{CO} 2$ incubator for 14 hours. The well contents transferred via harvester on filters (Whatman) and washed with saline, then with 5\% trichloroacetic acid solution and 95\% ethanol. The dried filters were placed in vials containing scintillation fluid.

\subsubsection{In Vitro Antitumor Activity of HTLP}

In the in vitro study human laryngeal carcinoma Hep-2 and murine aneuploidy fibrosarcoma L-929 were used. Duration of contact with the culture and polysaccharide was 24 hours. Evaluation of the drug action was made by counting the viable tumor cells staining with trypan blue, their comparison with the control cultures, and calculating the percentage of inhibition of cell growth.

\subsubsection{In vivo antimetastatic activity of HTLP in Walker carcinosarcoma model}

For in vivo study high-affinity strain of Walker carcinosarcoma was used. To study the effect of drugs on tumor cell metastasis convenient models are strains of transplantable tumors with selective cells organotropye and enhanced colonogenic capacity in conditions in vivo. To identify anti-tumor activity of the HTLP was used affinity strain of Walker carcinosarcoma which at inoculation into the tail vein of the «August»rats male and female 100-130 g weigh, forms tumor nodules in the lungs. HTLP was injected subcutaneously at a dose of 0.015 and $1.0 \mathrm{mg} / \mathrm{kg}$ daily, in different schedule. Clones were enucleated from rat lungs after decapitation. Different groups were formed:

1. Control -injection into tail vein of $0.2 \mathrm{ml}$ of $0.9 \% \mathrm{NaCl}$. Killing was performed on the 5 day after inoculation of tumor.

2. Control injection into tail vein of $0.2 \mathrm{ml}$ of $0.9 \% \mathrm{NaCl}$. Killing was performed on the 10 day after inoculation of tumor.

3. Injection of HTLP in amount $0.015 \mathrm{mg} / \mathrm{kg}$ after 3 days after inoculation every day. Killing was performed on the 5 day after first injection.

4. Injection of HTLP in amount $0.015 \mathrm{mg} / \mathrm{kg}$ after 3 days after inoculation every day. Killing was performed on the 10 day after first injection.

5. Injection of HTLP in amount $1.0 \mathrm{mg} / \mathrm{kg}$ after 3 days after inoculation each 2 days. Killing was performed on the 5 day after first injection.

6. Injection of HTLP in amount $1.0 \mathrm{mg} / \mathrm{kg}$ after 3 days after inoculation each 2 days. Killing was performed on the 10 day after first injection.

\subsubsection{In vivo antitumor and antimetastatic activity of HTLP in Lewis lung-carcinoma (LLC) model}

Shredded pieces of LLC tumor tissue were interwoven intramuscularly into mice back leg femoris. During tumor development in mice primary tumor weight was measured 5 times on $5,11,14,17$ and 20 day after tumor injection as a difference between weight of leg with tumor and without. Lungs weight and number of tumor cells colonies (lungs were fixed in Bowen solution) were also measured. 
$0.9 \% \mathrm{NaCl}$ solution of HTLP was injected subcutaneously on the 4 day after tumor injection in 0.5 and $5 \mathrm{mg} / \mathrm{kg}$ doses. Two course were studied - single and fivefold injection. After animal slaughter tumor tissues were taken for histology. To study antimetastatic activity of polysaccharide solution number of lung metastases was counted directly.

\section{RESUlTS AND DiscusSiON}

\subsection{Stimulation of Nk-Cells Activity by HTLP}

In table 1 influence of HTLP on the activity of Nk-cells is shown. Cytotoxicity index (CI) was calculated using equation: $\mathrm{CI}=(1-\mathrm{A} / \mathrm{B}) \times 100 \%$, where $\mathrm{A}$-number of impulses in test-wells, $\mathrm{B}-$ number of impulses in control wells. CI for K562 + PBL $=61.0 \pm 2.7$ and for K562 + PBL + HTLP $=$ $76.0 \pm 3.1$. Therefor growth of CI was $15.0 \%$ comparing with K562 + PBL group. In this experiment polysaccharide stimulated activity of Nk-cells in vitro.

Table1.Influence of HTLP on activity of Nk-cells.

\begin{tabular}{|l|l|l|l|l|l|l|}
\hline Cell culture & \multicolumn{4}{l|}{ Inclusion of ${ }^{3}$ H-uridine, imp/min } & M \pm m \\
\hline K562 & 3654 & 3415 & 3473 & 2987 & 2973 & 3300 \\
\hline K562 + HTLP & 2784 & 3290 & 2893 & 3589 & 3130 & 3173 \\
\hline K562+PBL & 1325 & 1169 & 1298 & 1047 & 1583 & 1284 \\
\hline K562 + PBL + HTLP & 687 & 756 & 834 & 739 & 697 & 743 \\
\hline
\end{tabular}

\subsection{In Vitro Antitumor Activity of HTLP}

The table 2 shows that the HTLP in doses 100 and $200 \mu \mathrm{g} / \mathrm{ml}$ shows antitumor activity, which leads to the destruction of oncological cells, what can be interpreted as cytotoxicity of HTLP. However in previous work it was shown that HTLP is not-toxic [1] and may be used as a colony-stimulator [2], so the reason of such activity probably is in activation of apoptosis in cancer cells.

Table2.Inhibition of tumour growth by polysaccharid $\mathrm{e}$

\begin{tabular}{|c|c|c|c|c|c|}
\hline & Cell line & Number of cells & $\begin{array}{c}\text { Dose of } \\
\text { polysaccharide } \mu \mathrm{g} / \mathrm{ml}\end{array}$ & $\begin{array}{c}\text { Number of cells in 24 hours } \\
\text { (Mean } \pm \text { SE) }\end{array}$ & Inhibition, \% \\
\hline 1 & control & $10 \times 10^{4}$ & - & $20 \times 10^{4} \pm 1.9$ & - \\
\hline 2 & Hep-2 & $10 \times 10^{4}$ & 100 & $18 \times 10^{4} \pm 1.2$ & 10 \\
\hline 3 & Hep-2 & $10 \times 10^{4}$ & 200 & $10 \times 10^{4} \pm 0.3$ & - \\
\hline 4 & control & $10 \times 10^{4}$ & - & $16 \times 10^{4} \pm 1.2$ & 37.5 \\
\hline 5 & L-929 & $10 \times 10^{4}$ & 100 & $10 \times 10^{4} \pm 1.2$ & 81.2 \\
\hline 6 & L-929 & $10 \times 10^{4}$ & 200 & $3 \times 10^{4} \pm 0.4$ & 40 \\
\hline
\end{tabular}

\subsection{In Vivo Antimetastatic Activity of HTLP In Walker Carcinosarcoma Model}

Tables 3 and 4 show that this substance has antimetastatic activity at high -100 pper animal and at low concentrations -1.5 pper animal. Moreover the similarity of antimetastatic activity of higher and lower doses with different time courses shows that biological effect of HTLP bases not only on the direct impact of the substance on the metastases, such as activation of apoptosis, but also on the trigger activation of the immune system. Such result corresponds with previous works, where was shown immunomodulatory activity and antiviral activity of HTLP in the way of stabilization of different cytokines [2,3] and stimulation of phagocytosis and with Nk-cells activity stimulation experiment.

Table3.Reduction of number of clones by HTLP in dose $0.015 \mathrm{mg} / \mathrm{kg}$

\begin{tabular}{|c|c|c|c|}
\hline \multicolumn{2}{|c|}{ Number of clones } & Day of the slaughter of animals & Metastatic inhibition (\% of control) \\
\hline $\begin{array}{c}\text { Control } \\
\mathrm{M} \pm \mathrm{M}\end{array}$ & $\begin{array}{c}\text { Experience } \\
\mathrm{M} \pm \mathrm{M}\end{array}$ & & \\
\hline $22.8 \pm 3.9$ & $16.2 \pm 3.7$ & 5 & 28.9 \\
\hline $79.0 \pm 11.7$ & $49.7 \pm 9.68$ & 10 & 37.1 \\
\hline
\end{tabular}


Table3.Reduction of number of clones by HTLP in dose $0.015 \mathrm{mg} / \mathrm{kg}$

\begin{tabular}{|c|c|c|c|}
\hline \multicolumn{2}{|c|}{ Number of clones } & $\begin{array}{c}\text { Day of the slaughter of } \\
\text { animals }\end{array}$ & $\begin{array}{c}\text { Metastatic inhibition }(\% \\
\text { of control) }\end{array}$ \\
\hline $\begin{array}{c}\text { Control } \\
M \pm M\end{array}$ & $\begin{array}{c}\text { Experience } \\
M \pm M\end{array}$ & \\
\hline $22.8 \pm 3.9$ & $16.2 \pm 3.7$ & 5 & 28.9 \\
\hline $79.0 \pm 11.7$ & $49.7 \pm 9.68$ & 10 & 37.1 \\
\hline
\end{tabular}

Table4.Reduction of number of clones by HTLP in dose $1.0 \mathrm{mg} / \mathrm{kg}$

\begin{tabular}{|c|c|c|c|}
\hline \multicolumn{2}{|c|}{ Number of clones } & \multirow{2}{*}{$\begin{array}{c}\text { Day of the slaughter of } \\
\text { animals }\end{array}$} & \multirow{2}{*}{$\begin{array}{c}\text { Metastatic inhibition (\% of } \\
\text { control) }\end{array}$} \\
\hline $\begin{array}{c}\text { Control } \\
\mathrm{M} \pm_{\mathrm{M}}\end{array}$ & $\begin{array}{c}\text { Experience } \\
\mathrm{M} \pm_{\mathrm{M}}\end{array}$ & & \\
\hline $22.8 \pm 3.9$ & $16.8 \pm 2.95$ & 5 & 26.3 \\
\hline $79.0 \pm 11.7$ & $49.6 \pm 9.68$ & 10 & 37.2 \\
\hline
\end{tabular}

3.4.In Vivo Antitumor And Antimetastatic Activity of HTLP In Lewis Lung-Carcinoma (LLC) Model

Influence of HTLP on weight of LLC primary tumor is shown in table 5. Difference in tumor-growth kinetics between treated and control animals served as the indictor of the growth-inhibition effect. The coefficient of tumor growth inhibition (TGI, \%) was determined according to the following relationship: TGI $=1-\mathrm{PT} / \mathrm{PC}$, where $\mathrm{P}$ is the weight of tumor in $\mathrm{C}-$ control, $\mathrm{T}$ - trial group. The maximum TGI obtained is $15 \%$. However, histologically tumors from trial group and control differ in control group necrosis started in central part on 14 day after LLC injection, in trial groups this process started on 11 day, and at 20 day was more widespread than in control. Such activity could be explained through immunological mechanism by activation of macrophages and Nk-cells. Probably course must be prolonged to reveal more explicit antitumor activity of HTLP.

Table5.Influence of HTLP on weight of LLC primary tumor

\begin{tabular}{|c|c|c|c|c|c|c|c|}
\hline \multirow[t]{2}{*}{ Group } & \multirow[t]{2}{*}{ Dose and course } & \multicolumn{5}{|c|}{ Tumor weight (mg, $\mathrm{M} \pm \mathrm{M})$} & \multirow{2}{*}{$\begin{array}{l}\text { Growth, } \\
\text { times }\end{array}$} \\
\hline & & 5 day & 11 day & 14 day & 17 day & 20 day & \\
\hline 1 & $\begin{array}{l}0.5 \mathrm{mg} / \mathrm{kgsingle} \\
\text { injection }\end{array}$ & $\begin{array}{l}790 \\
\pm 264\end{array}$ & $4465 \pm 652$ & $5780 \pm 735$ & $5682 \pm 965$ & $7472 \pm 441$ & 9.5 \\
\hline 2 & $\begin{array}{l}0.5 \\
\mathrm{mg} / \mathrm{kgfivefoldinjection}\end{array}$ & $\begin{array}{l}853 \\
\pm 216\end{array}$ & $3811 \pm 603$ & $5546 \pm 839$ & $7506 \pm 603$ & $7335 \pm 278$ & 8.6 \\
\hline 3 & $5.0 \mathrm{mg} / \mathrm{kgsingleinjection}$ & $\begin{array}{l}845 \\
\pm 149\end{array}$ & $4413 \pm 455$ & $5362 \pm 70$ & $7475 \pm 738$ & $7920 \pm 857$ & 9.4 \\
\hline 4 & $\begin{array}{l}5.0 \\
\mathrm{mg} / \mathrm{kgfivefoldinjection}\end{array}$ & $\begin{array}{l}905 \pm \\
347\end{array}$ & $4287 \pm 660$ & $5042 \pm 424$ & $5045 \pm 563$ & $7533 \pm 481$ & 8.3 \\
\hline 5 & Control & $\begin{array}{l}910 \pm \\
110\end{array}$ & $3983 \pm 512$ & $5401 \pm 381$ & $6643 \pm 381$ & $8630 \pm 313$ & 9.5 \\
\hline
\end{tabular}

Table 6 shows influence of polysaccharide from Helianthus tuberosus L. on the metastatic process. On the 14 day after injection of LLC there were up to 11 colonies of cancer cells in lungs in control group. Injection of $5 \mathrm{mg} / \mathrm{kg}$ (100 rper animal) effectively inhibits metastasis up to $60 \%$ comparing with control. On the 17 day antimetastatic effect was also observed in all trial groups comparing with control. The maximum antimetastatic activity of HTLP was observed in the group with single 


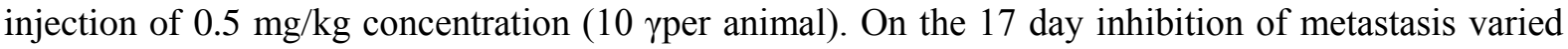
from 30 to $50 \%$. On the top of that inhibition of metastasis depending on dose and course varied from 50 to $80 \%$ on the 20 day. It has to be outlined that there were less number of cancer cells in metastatic colonies in animals administered $0.5 \mathrm{mg} / \mathrm{kg}$, what was observed on the smaller size of colonies in trials then in control group. All in all antimetastatic effect of HTLP solution in LLC model was up to $80 \%$ comparing with control.

Table6.Influence of HTLP on metastases of LLC

\begin{tabular}{|r|l|l|l|l|l|l|}
\hline Group* & Dose and course & \multicolumn{2}{|l|}{ Lung weight $(\mathrm{mg}, \mathrm{M} \pm \mathrm{M})$} \\
\cline { 3 - 7 } & & 5 day & 11 day & 14 day & 17 day & 20 day \\
\hline 1 & $\begin{array}{l}0.5 \mathrm{mg} / \mathrm{kg} \\
\text { singleinjection }\end{array}$ & $159.0 \pm 7.4$ & $157.3 \pm 26.5$ & $165.7 \pm 13.6$ & $114.0 \pm 11.3$ & $150.0 \pm 1.7$ \\
\hline 2 & $\begin{array}{l}0.5 \mathrm{mg} / \mathrm{kg} \\
\text { fivefoldinjection }\end{array}$ & $155.0 \pm 15.8$ & $158.7 \pm 13.4$ & $142.7 \pm 7.6$ & $147.0 \pm 7.0$ & $136.0 \pm 9.9$ \\
\hline 3 & $\begin{array}{l}5.0 \mathrm{mg} / \mathrm{kg} \\
\text { singleinjection }\end{array}$ & $152.5 \pm 13.4$ & $155.7 \pm 11.1$ & $142.0 \pm 5.7$ & $152.0 \pm 14.9$ & $147.3 \pm 4.7$ \\
\hline 4 & $\begin{array}{l}5.0 \mathrm{mg} / \mathrm{kg} \\
\text { fivefoldinjection }\end{array}$ & $139.5 \pm 51.6$ & $156.3 \pm 11.9$ & $164.3 \pm 32.4$ & $155.0 \pm 35.4$ & $166.0 \pm 4.0$ \\
\hline 5 & Control & $154.0 \pm 20.4$ & $158.7 \pm 7.4$ & $126.0 \pm 25.2$ & $145.3 \pm 6.4$ & $236.0 \pm 10.3$ \\
\hline 6 & Nativemice & & & & & $148.0 \pm 16.0$ \\
\hline
\end{tabular}

* Data was averaged for 5 animals

Most probably antimetastatic activity of HTLP is observed due to immunomodulatory activity. It was shown in previous work [12], that HTLP modulates activity of IL-6 and stimulates secretion of TNF.Tumor necrosis factor affects binding of TNF- $\alpha$ to TNFR-1 that leads to change ofhyperpermeability of the tumor vessels, and erythrocytes and other blood cells extravasate [14] and inducing immune-mediated necrosis of cancers $[15,16]$. At the same time IL-6 promotes epithelialmesenchymal transition, which leads to the growth of metastasis processes in head and neck cancers $[15,17]$, while HTLP decreases level of IL-6 when it is above normal .

\section{Conclusions}

Effect of Nk-cells activity stimulation was found and was expressed as in vitro increase of the cytotoxicity index by $15.0 \%$ comparing to control group K562 + PBL.

An antimetastatic activity of polysaccharide from Helianthus tuberosus L. was found, which was expressed as the inhibition of the development of tumor metastases to the lungs in model of Lewis lung-carcinoma by $80 \%$ on the 20 dayand up to $40 \%$ in model of Walker carcinosarcomacompared with control on the 10 day.

Also it was shown that in vitro polysaccharide also shows inhibition of tumor growth up to $40 \%$, what can be interpreted according to previous works as proapoptotic activity of polysaccharide from Helianthus tuberosus L. towards cancer cell lines. However, molecular mechanism of such antitumor activity is unclear and should be studied further.

\section{REFERENCES}

[1]. DranoffG., Cancer immunology and immunotherapy, 2011. 14. P. 306.

[2]. RezaeiN., Cancer immunology.Bench to bedside immunotherapy of cancers, Springer, 2015,P. 460.

[3]. Tzianabos A.O., Polysaccharide immunomodulators as therapeutic agents: structural aspects and biological function, Clinical Microbiology Review,13(4), 523-533(2000).

[4]. Schepetkin I.A., Quinn M.T., Botanical polysaccharides: Macrophage immunomodulation and therapeutic potential. International immunopharmacology,6(3), 317-333 (2006).

[5]. Ramberg J.E., Nelson E.D., Sinnott R.A., Immunomodulatory dietary polysaccharides: a systematic review of the literature, Nutrition Journal,9(54). 2(2010).

[6]. Fan Y., Lin M., Luo A., Chun Z., Luo A., Characterization and Antitumor Activity of a Polysaccharide from Sarcodiaceylonensis, Molecules,19, 10863-10876 (2014). 
[7]. Kimura Y., Sumiyoshi M., Suzuki T., Sakanara M., Antitumor and Antimetastatic Activity of a novel water-soluble low molecular weight ,-1, 3-D-glucan (branch ,-1,6) isolated from Aureobasidium pullulans 1A1 strain black yeast, Anticancer research,. 26, 4131-4142 (2006).

[8]. Song W., Hu P.,Shan Y., et al, Cartilage polysaccharide induces apoptosis in K562 cells through a reactive oxygen species-mediated caspase pathway, Food and function,5(10), 2486-2493 (2014).

[9]. Wang Z.,Lu C., Wu C., et al, Polysaccharide of Boshniakiarossica induces apoptosis on laryngeal carcinoma Hep2 cells, Gene,536(1), 203-206 (2014).

[10].Ooi V.E.C., Liu F., Immunomodulation and anti-cancer activity of polysaccharide-protein complexes, Current medicinal chemistry,7, 715-729 (2000).

[11].GeneralovE.A.,Water-soluble polysaccharide from Helianthus tuberosus L.: radioprotective, colony-stimulation and immunomodulation activities,60(1), 73-79 (2015).

[12].GeneralovE.A., Structure and radioprotective properties of non-toxic polysaccharide from Helianthus tuberosus L., Biophysics,59(3), 439-445 (2014).

[13]. GeneralovE.A.,Spectral characteristics and monosaccharide composition of interferon-inducing antiviral polysaccharide from Helianthus tuberosus L.,60(1),65-72 (2015).

[14].Horsen R., Hagen T.L.M., Eggermont A.M.M., TNF-a in cancer treatment: molecular insights, antitumor effects, and clinical utility, The Oncologist, 11(4), 397-408 (2006).

[15].Wells A., Chao Y.L., Grahovac J., Wu Q., and Lauffenburger D.A., Cell motility in carcinoma metastasis as modulated by switching between epithelial and mesenchymal phenotypes, Front Biosci. (Landmark Ed), 16,815-837 (2014).

[16]. Balkwill F., Tumor necrosis factor and cancer, Nat Rev Cancer, 9(5), 361-371 (2009).

[17]. Yadav A.,Kumar B.,Datta J.,Teknos T.N.,Kumar P., IL-6 promotes head and neck tumor metastasis by inducing epithelial-mesenchymal transition via the JAK-STAT3-SNAIL signaling pathway, Mol. Cancer Res., 9(12), 1658-1667 (2011). 